\title{
AGROTEKNIKA
}

ISSN: 2685-3450 (Online)

www.agroteknika.id

ISSN: 2685-3450 (Print)

\section{Pemanfaatan Pupuk Organik Cair NASA dalam Meningkatkan Produktivitas Bawang Merah di Daerah Wamena}

\section{Utilization of Organik Liquid Fertilizer NASA to Increase Productivity of Shallot in Wamena}

\author{
Sumiyati Tuhuteru*, ${ }^{*}$, Inrianti $^{1}$, Maulidiyah $^{2}$, Muhammad Nurdin $^{2}$ \\ ${ }^{1}$ Program Studi Agroteknologi, Sekolah Tinggi Ilmu Pertanian Petra Baliem Wamena, \\ Indonesia \\ ${ }^{2}$ Fakultas Matematika dan Ilmu Pengetahuan Alam, Jurusan Kimia, Universitas Haluoleo, \\ Indonesia \\ *Penulis Korespondensi: \\ Email: tuhuteru.umy@gmail.com
}

\begin{abstract}
Abstrak. Pupuk organik cair NASA ialah pupuk organik natural dari ekstrak bahan organik limbah ternak serta unggas, limbah sebagian tumbuhan tertentu dan zat-zat natural yang lain yang diproses dengan teknologi ramah lingkungan. Percobaan ini memiliki tujuan agar dapat mengetahui konsentrasi POC NASA yang pas bagi 5 varietas bawang merah yang ditanam di Wamena. Penelitian disusun dalam bentuk rancangan acak kelompok dua faktor. Faktor 1 berupa 5 varietas bawang merah, seperti Crok, Tiron, super Biru dan Bima serta satu varietas lokal Wamena sebagai pembanding. Sedangkan faktor 2 terdiri atas 3 taraf konsentrasi POC NASA yakni: $0 \mathrm{ml}, 150 \mathrm{ml}$ dan $250 \mathrm{ml}$. Informasi hasil penelitian dianalisis memakai ANOVA taraf $5 \%$. Apabila berpengaruh nyata, maka pengujian dianalisis lanjut dengan tes jarak berganda Duncan Multiple Range Test (DMRT) 5\%. Hasil percobaan membuktikan bahwa produktivitas tanaman bawang merah dipengaruhi oleh interaksi antara konsentrasi POC NASA dengan varietas bawang merah. Hasil penelitian memperlihatkan adanya interaksi nyata oleh perlakuan POC NASA $150 \mathrm{ml}$ dengan varietas Super Biru pada parameter tinggi tanaman dan bobot segar akar, kemudian perlakuan POC NASA $250 \mathrm{ml}$ dengan varietas Lokal Wamena pada parameter bobot kering daun, selanjutnya perlakuan POC NASA $250 \mathrm{ml}$ dengan varietas Bima pada pengamatan kandungan klorofil a dan jumlah daun.
\end{abstract}

Kata kunci: pupuk organik cair, bawang merah, produktivitas, wamena

Abstract. NASA's liquid organic fertilizer is a natural organic fertilizer from extracts of organic matter, livestock and poultry waste, certain plant wastes, and other organic substances that are processed with environmentally friendly technology. This experiment aims to determine the appropriate NASA concentrations with 5 varieties of shallots grown in Wamena. The research was arranged in a randomized block design with 2 factors, consisting of 5 shallots varieties, such as Crok, Tiron, Super Biru, Bima, and one local variety Wamena as a comparison. Meanwhile, factor 2 consists of 3 levels of NASA concentrations namely: 0 $\mathrm{ml}, 150 \mathrm{ml}$, and $250 \mathrm{ml}$. Research data were analyzed using ANOVA of 5\%. If it shows a real effect, then the test is continued with Duncan's Multiple Range Test (DMRT) of 5\%. The results showed that the productivity of shallot was influenced by the interactions between 
NASA concentrations and shallot varieties. The result showed a significant effect between NASA $150 \mathrm{ml}$ with Super Biru varieties on plant heigh and fresh weight of root parameters, then NASA $250 \mathrm{ml}$ treatment with Local Wamena varieties on dry weigh of leaf parameters, and then NASA $250 \mathrm{ml}$ treatment with Bima varieties on chlorophyll content and number of leaves.

Keywords: organic liquid fertilizer, productivity, wamena

\section{Pendahuluan}

Bawang merah (Allium cepa var. Agregatum L.) sebagai satu jenis produk utama sayuran yang bermanfaat dan merupakan kelompok rempah yang paling dibutuhkan oleh konsumen rumah tangga sebagai bumbu penyedap masakan, bahan baku industri makanan dan sebagai obat yang telah lama dikenal. Berlandaskan informasi yang diperoleh dari the National Nutrient Database, bawang merah mengandung karbohidrat, asam lemak, gula, protein dan mineral lain yang penting bagi manusia (Waluyo \& Sinaga, 2015). Peningkatan kebutuhan bawang merah terjadi bersamaan dengan peningkatan daya beli masyarakat. Supaya keberadaan bawang merah terpenuhi maka diperlukan keseimbangan dengan jumlah produksinya melalui pemanfaatan terobosan teknologi pembudidayaan tanaman bawang merah yang mampu menambah produksi tanaman terutama pada lahan sub-optimal Wamena, melalui pemanfaatan teknologi pemupukan secara organik. Hal ini dikarenakan, sistem pertanian organik di Wamena masih tergolong tradisional dan membutuhkan adanya pemanfaatan terobosan teknologi ramah lingkungan yang dapat membantu petani setempat.

Sistem pertanian organik mampu meningkatkan produktivitas tanaman, salah satunya adalah tanaman bawang merah, yang produktivitas tanamannya dapat dicapai melalui pemanfaatan pupuk organik alami (Samad, 2012). Salah satu jenis teknologi pemupukan yang telah dikembangkan adalah pemanfaatan pupuk organik alami yang diperuntukkan dalam mengatasi kendala dalam meningkatkan dan mempertahankan produksi pertanian. Seperti, rendahnya produksi tanaman yang dicapai dikarenakan petani sering meningkatkan pemberian pupuk an-organik melebihi dosis kebutuhan tanaman, padahal diketahui bahwa dengan pemupukan yang berlebihan akan berdampak selain pada tanaman juga pada tanah dan lingkungan sekitarnya.

Jenis pupuk organik berbahan dasara alami dan telah beredar dipasaran adalah pupuk organik cair (POC) NASA, yang berupa jenis pupuk natural yang kompisisnya terdiri dari ekstrak bahan alami yang berasal dari limbah ternak dan unggas, beberapa tanaman tertentu, zat-zat organik yang lain dan kemudian diolah menggunakan teknologi yang ramah lingkungan dengan asas Zero Emision Concept (Damari, 2012). POC NASA memiliki kemampuan mempercepat proses perkembangbiakkan tanaman, menurunkan tingkat 
serangan hama, dan tidak memiliki dampak buruk bagi tanaman dan lingkungan, serta baik untuk manusia (Natural Nusantara, 2004).

Pemupukan dengan menggunakan POC diketahui lebih baik karena memiliki beberapa keuntungan yakni lebih mudah diserap oleh akar dan dapat meningkatkan ketersediaan hara sesuai kebutuhan tanaman (Putri, 2011). Limbah sebagai bahan pokok dalam pembuatan pupuk organik tersedia dalam jumlah yang sangat banyak, seperti sampah rumah tangga, rumah makan, kotoran ternak, dan limbah organik lain (Nasaruddin \& Rosmawati, 2011).

Pupuk organik cair adalah cairan yang dihasilkan akibat proses pembusukan sampahsampah organik yang berupa sisa tanaman, kotoran ternak dan manusia yang unsur hara kompleks. Kelebihan pemanfaatan dari pupuk berbahan dasar alami ini diketahui secara cepat mengurangi proses defesiensi unsur hara bagi tanaman (menyediakan hara secara cepat) (Samad, 2008).

Wamena dikenal memiliki kondisi lahan sub-optimal dengan peluang pengembangan pertanian organik yang cukup memadai dalam pemenuhan pangan masyarakat tanpa harus mengimpor dari luar provinsi Papua. Akan tetapi, sistem pertanian organik yang diterapkan tergolong bersifat tradisional yang belum tersentuh oleh penerapan teknologi pada umumnya. Sistem pemupukan yang dilakukan petani sejauh ini tidak ada begut juga dengan teknik budidaya pertanian lainnya yang diketahui merupakan penopang keberlangsungan hidup suatu tanaman. Sistem pertanian organik yang diterapkan petani di Wamena sejauh ini bersifat ladang berpindah dan memanfaatkan alam semata. Untuk itu diperlukan teknik pengelolaan tanaman yang baik terutama dalam sistem pemupukan yang diketahui terkait kebutuhan hara tanaman. Diharapkan melalui pelaksanaan penelitian ini mampu berkontribusi bagi kehidupan petani setempat yang masih membutuhkan pemahaman dalam bidang pertanian organik, terutama terkait pupuk bagi tanaman.

Pupuk berperan penting dalam teknik budidaya tanaman karena tanaman membutuhkan unsur hara dalam mendukung produktivitas tanaman yang optimal. Percobaan ini tergolong baru bagi wilayah Wamena yang sistem pertanian organiknya telah dimasukkan kedalam peraturan daerah setempat (Tuhuteru et al., 2020). Meski sangat sederhana namun dapat menambah informasi bagi petani. Selain itu, sistem pertanian yang diterapkan sejauh ini masih memerlukan pengembangan, karena tergolong tradisional. Pemanfaatan pupuk organik cair pada pertanaman bawang merah dapat menambah pengetahuan petani dalam pengelolaan tanaman. Percobaan ini bertujuan dalam mengetahui dampak penggunaan POC NASA dengann konsentrasi yang tepat bagi pertumbuhan 5 varietas bawang merah yang ditanam pada lahan sub-optimal Wamena. 


\section{Bahan dan Metode}

\section{Alat dan Bahan}

Peralatan yang dipakai dalam percobaan ini yakni peralatan tanam berupa, sekop, cangkul, pisau, gembor, papan nama untuk setiap perlakuan, klorofil meter, spectrofotometer, timbangan analitik, perlengkapan laboratorium tanah dan ilmu tanaman, serta peralatan menulis.

Bahan yang dipakai terdiri atas lima jenis bawang merah: Crok, Tiron, Super Biru dan Bima serta satu varietas lokal Wamena sebagai pembanding, pupuk organik cair (POC) NASA, pupuk kandang sapi sebagai pupuk dasar, amplop dan plastik sebagai wadah sampel tanaman.

\section{Tahapan Penelitian}

Penelitian yang terdiri dari percobaan lima varietas bawang merah ini terdiri atas varietas Crok, Tiron, Super Biru, dan Bima serta satu varietas lokal Wamena sebagai pembanding. Perlakuan pemberian POC NASA terdiri dari 3 taraf, yakni perlakuan kontrol (tanpa POC NASA), perlakuan POC NASA $150 \mathrm{ml}$, dan perlakuan POC NASA $250 \mathrm{ml}$.

Percobaan ini dianalisis menggunakan rancangan acak kelompok 2 faktor, yakni faktor varietas dan faktor perlakuan pemberian POC NASA yang tiap perlakuannya diulang 2 kali, hingga terdapat 15 unit perlakuan dengan total perlakuan sebanyak 24 bedeng, yang berukuran $3 \times 1 \mathrm{~m}$.

Sebelum dilakukan penanaman, umbi bawang terlebih dahulu di sortir, dengan memilih jenis umbi yang tergolong sehat. Kemudian, umbi bawang yang terpilih dipotong 1/3 bagian dari atas baru kemudian dibenamkan ke tanah (bedengan) yang telah ditugal dengan bantuan penugal. Bedeng yang ditugal sebelumnya telah diberi pupuk kandang kotoran sapi, yang dibiarkan selama 3 hari sebelum penanaman dilakukan, yang kemudian dilakukan penyiraman. Hal ini bertujuan untuk melembabkan tanah yang akan ditanami umbi bawang merah. Penanaman dilakukan dengan jarak 20 x $15 \mathrm{~cm}$. Setelah umbi bawang merah ditanam, tahapan selanjutnya adalah pengaplikasian POC NASA sesuai dengan perlakuan yang telah ditetapkan. Pemberian POC NASA dilakukan sebanyak 3 kali, yakni pada awal sebelum penanaman, saat tanaman berumur 6 dan 12 minggu setelah tanam (MST). Kemudian, tahapan pemeliharaan yang dilakukan setiap 2 minggu sekali terhadap gulma yang tumbuh diarea pertanaman dan pemberantasan hama penyakit yang dilakukan secara organik dengan menggunakan jenis pestisida nabati seperti daun tembakau dan serai. Selama masa pertanaman berlangsung tidak ditemukan serangan hama maupun penyakit. 
Analisis pertumbuhan dilaksanakan untuk mengetahui pertumbuhan tanaman melalui parameter tinggi dan total daun tanaman bawang merah, yang diamati saat umur 11 dan 13 minggu setelah tanam (MST). Selanjutnya dilakukan analisis fisiologis tanaman untuk mengetahui proses fisiologis tanaman, yang dilakukan secara destruktif terhadap tanaman sampel. Parameter yang diamati meliputi: Bobot segar daun dan bobot kering daun (11 MST), Bobot segar akar dan bobot kering akar (11 MST), laju pertumbuhan nisbi (13 MST), kandungan klorofil a dan b (13 MST). Selanjutnya, tahapan pemanenan yang dilakukan saat tanaman berumur 13 MST dengan parameter yang menjadi tolak ukur adalah bobot kering umbi (ton.ha-1), pengamatan dilakukan dengan mengeringkan umbi melalui proses penjemuran selama 3-5 hari.

\section{Metode Analisis}

Informasil hasil percobaan yang diperoleh, dianalisis lebih lanjut memakai ANOVA 5\%. Jika hasil pengujian menunjukkan adanya pengaruh atau interaksi, pengujian akan dianalisis lanjut menggunakan tes jarak berganda Duncan Multiple Range Test (DMRT) 5\%.

\section{Hasil dan Pembahasan}

\section{Respon Pertumbuhan Tanaman}

Informasil penelitian untuk parameter tinggi dan perhitungan jumlah daun tanaman bawang merah memperlihatkan pengaruh nyata oleh kombinasi perlakuan POC NASA dengan jenis varietas. Hal ini ditunjukkan pada Tabel 1, terlihat pada parameter tinggi tanaman berpengaruh nyata yang ditunjukkan oleh interaksi antara perlakuan POC NASA $150 \mathrm{ml}$ dengan varietas Super Biru pada umur pengamatan 11 MST $(9,34 \mathrm{~cm})$ dan berpengaruh nyata terhadap perlakuan NASA $150 \mathrm{ml}$ yang dikombinasikan dengan varietas Bima $(4,98 \mathrm{~cm})$. Ini membuktikan bahwa terdapat peningkatan kandungan hara bagi tanaman melalui penambahan POC NASA sebanyak $150 \mathrm{ml}$. Penambahan POC NASA diketahui mampu meningkatkan kandungan hara yang diperlukan tanaman erutama hara makro seperti $\mathrm{N}$. N diketahui penting bagi pertumbuhan vegetatif suatu tanaman. Hal ini juga dikemukakan oleh Prihmantoro (1999), dimana N merupakan unsur penting bagi pertumbuhan daun, batang dan akar selama fase vegetatif berlangsung. Kemudian didukung oleh, Elisabet et al. (2013) yang mengemukakan bahwa penambahan ukuran tanaman dan daun-daun baru pada tanaman secara optimal dapat terjadi, apabila kebutuhan unsur-unsur pertumbuhan tanaman tercukupi.

Selanjutnya, terlihat adanya perbedaan respon yang ditunjukkan tanaman bawang merah pada pengamatan 13 MST yang berpengaruh nyata oleh perlakuan tanpa pemberian NASA $(0 \mathrm{ml})$ yang dikombinasikan dengan varietas lokal Wamena. Hal ini menunjukkan 
pemberian POC NASA pada pengamatan 13 MST untuk parameter tinggi tanaman tidak menunjukkan pengaruh atau dapat dikatakan dosis yang diberikan tidak mencukupi kebutuhan pertumbuhan tanaman pada minggu tersebut. Hal ini seperti pernyataan Juanda et al. (2018) bahwa POC NASA adalah salah satu jenis pupuk cair yang jika penggunaannya dilakukan pada waktu dan dengan konsentrasi yang tepat, maka dapat meningkatkan proses penyerapan unsur hara oleh tanaman karena keberadaan hara dalam tanah meningkat dan juga apabila diimbangi dengan pemeliharaan dan pemupukan yang baik mampu menambah produktivitas tanaman minimal 10\% jika dibanding dengan tanaman yang tidak berikan POC NASA.

Tabel 1. Tinggi tanaman bawang merah $(\mathrm{cm})$ Varietas Crok, Super Biru, Tiron, Lokal Wamena dan Bima

\begin{tabular}{|c|c|c|c|c|c|}
\hline \multirow{2}{*}{$\begin{array}{c}\text { Pengamatan } \\
\text { (MST) }\end{array}$} & \multirow{2}{*}{ Varietas } & \multicolumn{3}{|c|}{ Perlakuan POC NASA } & \multirow{2}{*}{ Rerata } \\
\hline & & $0 \mathrm{ml}$ & $150 \mathrm{ml}$ & $250 \mathrm{ml}$ & \\
\hline \multirow{7}{*}{11} & Crok & $9,10 \mathrm{a}$ & $8,58 \mathrm{abc}$ & $9,00 \mathrm{ab}$ & $8,89 \mathrm{a}$ \\
\hline & Tiron & 7,42 abcd & $8,67 \mathrm{abc}$ & 7,17 abcd & $8,86 \mathrm{a}$ \\
\hline & Super Biru & $8,50 \mathrm{abc}$ & $9,34 \mathrm{a}$ & $8,75 \mathrm{abc}$ & $6,70 \mathrm{bc}$ \\
\hline & Lokal Wamena & $6,84 \mathrm{abcd}$ & $7,00 \mathrm{abcd}$ & $6,25 \mathrm{bcd}$ & $7,48 \mathrm{ab}$ \\
\hline & Bima & $6,15 \mathrm{~cd}$ & $4,98 \mathrm{~d}$ & $5,30 \mathrm{~d}$ & $5,48 \mathrm{c}$ \\
\hline & Rerata & $7,60 \mathrm{a}$ & $7,71 \mathrm{a}$ & $7,29 \mathrm{a}$ & $(+)$ \\
\hline & & \multicolumn{4}{|c|}{$\mathrm{KK}: 15,08$} \\
\hline \multirow{6}{*}{13} & Crok & 9,84 abcd & 9,09 abcd & $10,34 \mathrm{abc}$ & $9,76 \mathrm{~b}$ \\
\hline & Tiron & 8,92 abcd & $10,25 \mathrm{abc}$ & 8,67 abcd & $9,28 \mathrm{~b}$ \\
\hline & Super Biru & 9,00 abcd & $9,75 \mathrm{abcd}$ & $8,33 \mathrm{bcd}$ & $9,04 \mathrm{~b}$ \\
\hline & Lokal Wamena & $12,25 \mathrm{a}$ & $11,33 \mathrm{ab}$ & $11,50 \mathrm{ab}$ & $11,69 \mathrm{a}$ \\
\hline & Bima & $7,39 \mathrm{dc}$ & $6,47 \mathrm{~d}$ & $6,27 \mathrm{~d}$ & $6,71 \mathrm{c}$ \\
\hline & Rerata & $9,48 \mathrm{a}$ & $9,38 \mathrm{a}$ & $9,02 \mathrm{a}$ & $(+)$ \\
\hline
\end{tabular}

Keterangan: Bilangan pada satu kolom dan/atau baris apabila diikuti dengan huruf yang sama membuktikan tidak adanya interaksi atau tidak berpengaruh nyata oleh DMRT dengan $\alpha=5 \% ;(+)$ : adanya interaksi antara perlakuan yang dicoba.

Varietas lokal merupakan bawang merah jenis varietas Wamena yang dapat bertahan hidup pada sistem pertanian tanpa teknik budidaya yang memadai. Sehingga meskipun tidak diberikan penambahan POC NASA, tanaman masih dapat berkembang dengan baik. Ini dipengaruhi oleh kemampuan fisiologis tanaman dan genetik tanaman tersebut.

Hasil penelitian menunjukkan pengaruh nyata POC NASA terhadap varietas bawang merah yang diuji coba terhadap jumlah daun seperti yang terlihat pada Tabel 2. Hasil penelitian menandakan bahwa POC NASA sebanyak $250 \mathrm{ml}$ yang dikombinasikan dengan varietas Bima menunjukkan jumlah daun terbanyak (30,34 helai) dan berpengaruh nyata terhadap perlakuan Kontrol (Tanpa POC NASA) yang dikombinasikan dengan varietas Lokal 
Wamena (14,500 helai). Banyaknya jumlah daun yang terbentuk pada tanaman ini diketahui pada akhirnya akan berpengaruh pada jumlah fotosintat yang dihasilkan.

Tabel 2. Total daun (helai) varietas Crok, Super Biru, Tiron, Lokal Wamena dan Bima

\begin{tabular}{|c|c|c|c|c|c|}
\hline \multirow{2}{*}{$\begin{array}{l}\text { Pengamatan } \\
\text { (MST) }\end{array}$} & \multirow{2}{*}{ Varietas } & \multicolumn{3}{|c|}{ Perlakuan POC NASA } & \multirow{2}{*}{ Rerata } \\
\hline & & $0 \mathrm{ml}$ & $150 \mathrm{ml}$ & $250 \mathrm{ml}$ & \\
\hline \multirow{7}{*}{11} & Crok & $23,17 \mathrm{abc}$ & $25,67 \mathrm{abc}$ & $24,50 \mathrm{abc}$ & $24,44 \mathrm{a}$ \\
\hline & Tiron & $29,34 \mathrm{ab}$ & $24,17 \mathrm{abc}$ & $25,17 \mathrm{abc}$ & $26,22 \mathrm{a}$ \\
\hline & Super Biru & $26,83 \mathrm{ab}$ & $27,34 \mathrm{ab}$ & $22,00 \mathrm{bc}$ & $25,39 \mathrm{a}$ \\
\hline & Lokal Wamena & $14,50 \mathrm{~d}$ & $18,50 \mathrm{~cd}$ & $22,50 \mathrm{abc}$ & $18,50 \mathrm{~b}$ \\
\hline & Bima & $25,67 \mathrm{abc}$ & $29,00 \mathrm{ab}$ & $30,34 \mathrm{a}$ & $28,34 \mathrm{a}$ \\
\hline & Rerata & $23,90 \mathrm{a}$ & $24,93 \mathrm{a}$ & $24,90 \mathrm{a}$ & $(+)$ \\
\hline & \multicolumn{5}{|c|}{ KK: 13,57} \\
\hline \multirow{6}{*}{13} & Crok & $25,34 \mathrm{a}$ & $28,50 \mathrm{a}$ & $30,00 \mathrm{a}$ & $27,95 \mathrm{a}$ \\
\hline & Tiron & $26,34 \mathrm{a}$ & $26,00 \mathrm{a}$ & $25,67 \mathrm{a}$ & $26,00 \mathrm{a}$ \\
\hline & Super Biru & $28,00 \mathrm{a}$ & $26,67 \mathrm{a}$ & $25,17 \mathrm{a}$ & $26,61 \mathrm{a}$ \\
\hline & Lokal Wamena & $24,00 \mathrm{a}$ & $24,50 \mathrm{a}$ & $27,50 \mathrm{a}$ & $25,33 \mathrm{a}$ \\
\hline & Bima & $30,17 \mathrm{a}$ & $30,67 \mathrm{a}$ & $24,50 \mathrm{a}$ & $28,44 \mathrm{a}$ \\
\hline & Rerata & $26,77 \mathrm{a}$ & $27,27 \mathrm{a}$ & $26,57 \mathrm{a}$ & $(-)$ \\
\hline
\end{tabular}

Keterangan: Bilangan pada satu kolom dan/atau baris apabila diikuti dengan huruf yang sama membuktikan tidak adanya interaksi atau tidak berpengaruh nyata oleh DMRT dengan $\alpha=5 \% ;(+)$ : ada interaksi antara perlakuan yang dicoba.

Pertambahan daun pada tanaman mengakibatkan berkurangnya penampang permukaan daun per individu tanaman, tetapi luas daun yang diperoleh akan bertambah per tanaman (Umarie et al., 2018). Hal ini dipengaruhi oleh daya serap dan perubahan energi cahaya yang terjadi pada proses pengisian biji dan hasil tanaman yang didasarkan oleh banyaknya daun tanaman yang terbentuk, disebabkan karena daun pada tanaman adalah tempat terjadinya proses asimilasi yang penting bagi tanaman, jika luas daun tanaman bertambah maka, penyerapan cahaya oleh daun tanaman diketahui mengalami peningkatan. Diketahui bahwa diperlukan area pertumbuhan bagi tanaman yang cukup dalam mengoptimalkan penerimaan cahaya matahari, nutrisi dan air yang dibutuhkan tanaman (Buhaira, 2007).

Pemberian POC NASA dengan konsentrasi yang tepat mampu meningkatkan proses penyerapan unsur hara, cahaya dan air sehingga mampu mengoptimalkan pertumbuhan tanaman, serta berpengaruh pada pembentukan organ tanaman. Selain itu, pemberian POC NASA juga menambah keberadaan serta daya serap nutrisi bagi tanaman yang terdiri atas unsur hara makro dan mikro bagi tanaman untuk memperoleh hasi panen yang optimum. Karena dengan penambahan POC NASA mampu mengoptimalkan nutrisi kompleks yang penting bagi tanaman bawang merah (Nugrahini, 2013). 


\section{Respon Fisiologis Tanaman}

Selain pertumbuhan tanaman, pemberian POC NASA juga berpengaruh pada parameter fisiologis tanaman, seperti bobot segar akar dan bobot kering akar (Tabel 3). Informasi hasi percobaan membuktikan adanya pengaruh pada perlakuan POC NASA dengan varietas tanaman bawang terhadap bobot segar akar tanaman. Selain itu diduga dengan kemampuan adaptif yang dimiliki, varietas lokal Wamena mampu menyimpan air pada sistem perakarannya sehingga berpengaruh pada bobot segar akar tanaman (Tuhuteru et al., 2019).

Tabel 3. Bobot segar akar dan bobot kering akar (gr) Varietas Crok, Super Biru, Tiron, Lokal Wamena dan Bima pada 11 MST

\begin{tabular}{|c|c|c|c|c|c|}
\hline \multirow{2}{*}{$\begin{array}{c}\text { Parameter } \\
\text { Pengamatan }\end{array}$} & \multirow{2}{*}{ Varietas } & \multicolumn{3}{|c|}{ Perlakuan POC NASA } & \multirow{2}{*}{ Rerata } \\
\hline & & $0 \mathrm{ml}$ & $150 \mathrm{ml}$ & $250 \mathrm{ml}$ & \\
\hline \multirow{7}{*}{$\begin{array}{l}\text { Bobot Segar Akar } \\
\text { (gr) }\end{array}$} & Crok & $1,29 \mathrm{~b}$ & $1,12 \mathrm{~b}$ & $1,42 \mathrm{~b}$ & $1,27 \mathrm{~b}$ \\
\hline & Tiron & $1,64 \mathrm{ab}$ & $1,10 \mathrm{~b}$ & $1,39 \mathrm{~b}$ & $1,37 \mathrm{ab}$ \\
\hline & Super Biru & $1,34 \mathrm{~b}$ & $2,29 \mathrm{a}$ & $1,76 a b$ & $1,79 \mathrm{a}$ \\
\hline & Lokal Wamena & $1,67 \mathrm{a}$ & $1,59 \mathrm{ab}$ & $1,64 a b$ & $1,64 \mathrm{ab}$ \\
\hline & Bima & $1,56 \mathrm{ab}$ & $1,26 \mathrm{~b}$ & $1,21 \mathrm{~b}$ & $1,34 \mathrm{~b}$ \\
\hline & Rerata & $1,50 \mathrm{a}$ & $1,46 \mathrm{ab}$ & $1,49 \mathrm{a}$ & $(+)$ \\
\hline & \multicolumn{5}{|c|}{ KK: 22,32} \\
\hline \multirow{6}{*}{$\begin{array}{l}\text { Bobot Kering Akar } \\
\text { (gr) }\end{array}$} & Crok & $0,74 \mathrm{a}$ & $1,12 \mathrm{a}$ & $0,98 \mathrm{a}$ & $0,95 \mathrm{ab}$ \\
\hline & Tiron & $0,72 \mathrm{a}$ & $0,51 \mathrm{a}$ & $0,66 \mathrm{a}$ & $0,63 \mathrm{~b}$ \\
\hline & Super Biru & $1,02 \mathrm{a}$ & $1,59 \mathrm{a}$ & $1,54 \mathrm{a}$ & $1,38 \mathrm{a}$ \\
\hline & Lokal Wamena & $1,08 \mathrm{a}$ & $0,67 \mathrm{a}$ & $0,92 \mathrm{a}$ & $0,89 a b$ \\
\hline & Bima & $1,07 \mathrm{a}$ & $1,24 \mathrm{a}$ & $1,21 \mathrm{a}$ & $1,17 \mathrm{ab}$ \\
\hline & Rerata & $0,92 \mathrm{a}$ & $1,02 \mathrm{a}$ & $1,06 \mathrm{a}$ & $(-)$ \\
\hline
\end{tabular}

Keterangan: Bilangan pada satu kolom dan/atau baris apabila diikuti dengan huruf yang sama membuktikan tidak adanya interaksi atau tidak berpengaruh nyata oleh DMRT dengan $\alpha=5 \%$; $(+)$ : ada interaksi antara perlakuan yang dicoba.

Informasi hasil percobaan menandakan tidak ditemukan adanya interaksi atau percobaan yang dilakukan tidak berpengaruh nyata pada pemberian POC NASA dengan varietas tanaman bawang pada parameter bobot kering akar tanaman bawang. Tetapi, hasil penelitian dari respon jenis varietas yang diuji coba menunjukkan pengaruh nyata oleh varietas Super Biru (1,38 gr). Padahal terlihat pada pengamatan bobot segar akar, varietas Lokal Wamena menunjukkan rerata tertinggi dibanding varietas lainnya. Hal ini diduga bahwa kandungan air dalam sistem perakarannya dapat hilang dengan cepat saat ditimbang atau daya simpan air dalam sistem perakarannya terbilang rendah sehingga hilang saat dikeringkan. Selain bobot segar dan kering akar yang diamati, pada parameter bobot segar dan kering daun terlihat respon yang berbeda yang ditunjukkan oleh masing-masing perlakuan dan varietas yang diuji coba seperti yang terlihat di Tabel 4. 
Tabel 4. Bobot segar daun dan bobot kering daun (gr) Varietas Crok, Super Biru, Tiron, Lokal Wamena dan Bima pada 11 MST

\begin{tabular}{|c|c|c|c|c|c|}
\hline \multirow{2}{*}{$\begin{array}{c}\text { Parameter } \\
\text { Pengamatan }\end{array}$} & \multirow{2}{*}{ Varietas } & \multicolumn{3}{|c|}{ Perlakuan POC NASA } & \multirow{2}{*}{ Rerata } \\
\hline & & $0 \mathrm{ml}$ & $150 \mathrm{ml}$ & $250 \mathrm{ml}$ & \\
\hline \multirow{7}{*}{$\begin{array}{c}\text { Bobot Segar } \\
\text { Daun } \\
(\mathrm{gr})\end{array}$} & Crok & $1,60 \mathrm{a}$ & $1,83 \mathrm{a}$ & $2,82 \mathrm{a}$ & $2,08 \mathrm{a}$ \\
\hline & Tiron & $1,39 \mathrm{a}$ & $2,17 \mathrm{a}$ & $2,16 \mathrm{a}$ & $1,90 \mathrm{~b}$ \\
\hline & Super Biru & $2,15 \mathrm{a}$ & $1,78 \mathrm{a}$ & $2,07 \mathrm{a}$ & $2,00 \mathrm{a}$ \\
\hline & Lokal Wamena & $1,74 \mathrm{a}$ & $2,39 \mathrm{a}$ & $3,02 \mathrm{a}$ & $2,38 \mathrm{a}$ \\
\hline & Bima & $2,99 \mathrm{a}$ & $2,17 \mathrm{a}$ & $1,48 \mathrm{a}$ & $2,21 \mathrm{a}$ \\
\hline & Rerata & $1,97 \mathrm{a}$ & $2,07 \mathrm{a}$ & $2,31 \mathrm{a}$ & $(-)$ \\
\hline & \multicolumn{5}{|c|}{ KK: 41,46} \\
\hline \multirow{6}{*}{$\begin{array}{l}\text { Bobot Kering } \\
\text { Daun } \\
\text { (gr) }\end{array}$} & Crok & $2,94 \mathrm{ab}$ & $2,68 \mathrm{~b}$ & $3,68 \mathrm{ab}$ & $3,10 \mathrm{ab}$ \\
\hline & Tiron & $2,16 \mathrm{~b}$ & $3,24 \mathrm{ab}$ & $3,34 \mathrm{ab}$ & $2,91 \mathrm{ab}$ \\
\hline & Super Biru & $2,85 \mathrm{ab}$ & $2,54 \mathrm{~b}$ & $2,61 \mathrm{~b}$ & $2,67 a b$ \\
\hline & Lokal Wamena & $2,48 \mathrm{~b}$ & $3,12 \mathrm{ab}$ & $4,86 \mathrm{a}$ & $3,48 \mathrm{a}$ \\
\hline & Bima & $1,71 \mathrm{~b}$ & $2,68 \mathrm{~b}$ & $1,88 \mathrm{~b}$ & $2,09 \mathrm{~b}$ \\
\hline & Rerata & $2,43 \mathrm{a}$ & $2,85 \mathrm{a}$ & $3,28 \mathrm{a}$ & $(+)$ \\
\hline
\end{tabular}

Keterangan: Bilangan pada satu kolom dan/atau baris apabila diikuti dengan huruf yang sama membuktikan tidak adanya interaksi atau tidak berpengaruh nyata oleh DMRT dengan $\alpha=5 \%$; $(+)$ : ada interaksi antara perlakuan yang dicoba.

Hasil pengamatan terhadap parameter bobot segar daun menandakan adanya pengaruh yang tidak nyata. Namun, tanggapan yang ditunjukkan jenis varietas menunjukkan pengaruh nyata oleh varietas Lokal Wamena (2,38 gr) terhadap varietas Crok. Sedangkan, hasil pengamatan terhadap parameter bobot kering daun menunjukkan adanya interaksi antara jenis varietas dengan konsentrasi POC NASA yakni, kombinasi antara perlakuan POC NASA 250 $\mathrm{ml}$ dengan varietas Lokal Wamena (4,86 gr). Varietas lokal Wamena memiliki daya adaptif dibanding varietas lain, dimana kemampuannya terlihat pada saat fase generatif tanaman. Salah satunya adalah kemampuan membentuk umbi dengan ukuran besar (Tuhuteru et al., 2019). Seperti pernyataan Supariadi et al. (2017) yang menyatakan bahwa bobot umbi bawang merah yang optimal berhubungan erat banyaknya daun tanaman bawang merah. Semakin banyak daun yang terbentuk diketahui dapat memacu proses asimilasi tanaman yang mampu menghasilkan jumlah asimilat terbanyak, yang selanjutnya dapat dihantar ke umbi sebagai organ penyimpanan. Jumlah asimilat yang tersimpan diketahui mampu menambah bobot tanaman sebagai bentuk dari jumlah asimilat yang dihasilkan tanaman tersebut. Hal ini juga didukung oleh Nur (2010) yang mengemukakan bahwa bobot kering total tanaman (bobot kering daun, batang dan akar) dipakai sebagai parameter dalam mengetahui kemampuan tanaman membentuk asimilat yang merupakan hasil dari proses fotosintesis tanaman. Selain itu, hasil pengamatan terhadap parameter bobot segar daun dan bobot kering daun, berhubungat langsung dengan kandungan klorofil tanaman, yang pada akhirnya 
berpengaruh pada umbi yang terbentuk. Hasil penelitian terhadap kandungan klorofil a dan $b$ tanaman menunjukkan pengaruh yang bervariasi (Tabel 5).

Pengamatan kandungan klorofil a menunjukkan adanya interaksi perlakuan antara perlakuan POC NASA dengan varietas yang diuji coba. Hasil penelitian menunjukkan pengaruh nyata oleh kombinasi perlakuan POC NASA $250 \mathrm{ml}$ dengan varietas Bima $(0,17$ mg. $\left.\mathrm{g}^{-1}\right)$. Sedangkan, pengamatan kandungan klorofil $\mathrm{b}$ tidak berpengaruh nyata baik secara interaksi maupun mandiri dari setiap perlakuan. Sebagaimana banyaknya jumlah daun yang terbentuk terlihat pada pemberian POC NASA dengan varietas Bima, pada akhirnya berpengaruh pada kandungan klorofil a meskipun pada kandungan klorofil b tidak menunjukkan pengaruh nyata. Diketahui bahwa, jumlah klorofil dan $\mathrm{CO}_{2}$ yang diserap tanaman berpengaruh terhadap laju fotosintesis. Dimana, proses asimilasi ini didukung oleh keberadaan hara $\mathrm{P}$ dan konsentrasi $\mathrm{CO}_{2}$ yang diserap tanaman yang juga dipengaruhi dengan adanya daya hantar $\mathrm{H}_{2} \mathrm{O}$ dalam stomata daun tanaman (Lakitan, 2001).

Tabel 5. Klorofil tanaman bawang merah (mg.g $\left.{ }^{-1}\right)$ Varietas Crok, Super Biru, Tiron, Lokal Wamena dan Bima

\begin{tabular}{|c|c|c|c|c|c|}
\hline \multirow{2}{*}{ Klorofil } & \multirow{2}{*}{ Varietas } & \multicolumn{3}{|c|}{ Perlakuan POC NASA } & \multirow{2}{*}{ Rerata } \\
\hline & & $0 \mathrm{ml}$ & $150 \mathrm{ml}$ & $250 \mathrm{ml}$ & \\
\hline \multirow{7}{*}{$\mathrm{a}$} & Crok & $0,15 \mathrm{ab}$ & $0,12 \mathrm{abc}$ & $0,08 \mathrm{abc}$ & $0,10 \mathrm{a}$ \\
\hline & Tiron & $0,14 \mathrm{abc}$ & $0,07 \mathrm{c}$ & $0,09 \mathrm{ab}$ & $0,09 \mathrm{a}$ \\
\hline & Super Biru & $0,11 \mathrm{abc}$ & $0,14 \mathrm{abc}$ & $0,08 \mathrm{abc}$ & $0,11 \mathrm{a}$ \\
\hline & Lokal Wamena & $0,08 \mathrm{abc}$ & $0,06 \mathrm{bc}$ & $0,06 \mathrm{c}$ & $0,06 \mathrm{a}$ \\
\hline & Bima & $0,08 \mathrm{abc}$ & $0,12 \mathrm{abc}$ & $0,17 \mathrm{a}$ & $0,11 \mathrm{a}$ \\
\hline & Rerata & $0,11 \mathrm{a}$ & $0,09 \mathrm{a}$ & $0,09 \mathrm{a}$ & $(+)$ \\
\hline & & \multicolumn{4}{|c|}{ KK: 38,93} \\
\hline \multirow{6}{*}{$\mathrm{b}$} & Crok & $0,07 \mathrm{a}$ & $0,08 \mathrm{a}$ & $0,05 \mathrm{a}$ & $0,07 \mathrm{a}$ \\
\hline & Tiron & $0,08 \mathrm{a}$ & $0,05 \mathrm{a}$ & $0,06 \mathrm{a}$ & $0,06 \mathrm{a}$ \\
\hline & Super Biru & $0,07 \mathrm{a}$ & $0,09 \mathrm{a}$ & $0,06 \mathrm{a}$ & $0,07 \mathrm{a}$ \\
\hline & Lokal Wamena & $0,06 \mathrm{a}$ & $0,04 \mathrm{a}$ & $0,04 \mathrm{a}$ & $0,05 \mathrm{a}$ \\
\hline & Bima & $0,05 \mathrm{a}$ & $0,07 \mathrm{a}$ & $0,09 \mathrm{a}$ & $0,07 \mathrm{a}$ \\
\hline & Rerata & $0,07 \mathrm{a}$ & $0,07 \mathrm{a}$ & $0,06 \mathrm{a}$ & $(-)$ \\
\hline
\end{tabular}

Keterangan: Bilangan pada satu kolom dan/atau baris apabila diikuti dengan huruf yang sama membuktikan tidak adanya interaksi atau tidak berpengaruh nyata oleh DMRT dengan $\alpha=5 \% ;(+)$ : ada interaksi antara perlakuan yang dicoba.

Unsur $\mathrm{P}$ adalah unsur penting pada proses asimilasi tanaman seperti dalam proses fotosintesis, karena proses ini memerlukan energi dalam bentuk ATP yang diperoleh dari keberadaan unsur P yang diserap oleh tanaman. Hal ini didukung oleh pernyataan Singh and Reddy (2014) bahwa kekurangan unsur P dapat menurunkan proses fotosintesis akibat dari jumlah energy yang rendah. Kemudian, terkait konsentrasi $\mathrm{CO}_{2}$ dalam tubuh tanaman saat tanaman memfiksasinya di atmosfer, tanaman melepaskan $\mathrm{H}_{2} \mathrm{O}$ yang dapat menyebabkan 
terjadi penambahan daya hantar $\mathrm{H}_{2} \mathrm{O}$ dalam daun yang berpengaruh pada konsentrasi $\mathrm{CO}_{2}$ didalam sel tanaman. Menurut Von and Farquhar (1981) molekul $\mathrm{H}_{2} \mathrm{O}$ yang dilepaskan keluar dari stomata berpengaruh pada keberadaan molekul $\mathrm{CO}_{2}$ didalam stomata, yang jika terjadi secara konsisten maka akan berpengaruh pada laju pertumbuhan nisbi tanaman bawang merah sesuai dengan data di Tabel 6.

Tabel 6 menunjukkan dampak nyata pada kombinasi percobaan Kontrol dengan varietas Tiron. Hal ini dipengaruhi oleh banyaknya daun yang terbentuk pada varietas Tiron, sehingga berpengaruh pada bobot kering tanaman yang dihasilkan. Kesanggupan tanaman memperoleh bobot keringnya dicerminkan melalui laju pertumbuhan tanaman tersebut (Gardner et al., 1991). Dengan kata lain, laju pertumbuhan nisbi tanaman (LPN) merupakan proses pertambahan bobot kering yang dihasilkan tanaman per luasan lahan dalam satuan waktu. Bertambahnya jumlah daun diduga dipengaruhi oleh kandungan asilmilat yang tersimpan untuk dijadikan bahan makanan, yang selanjutnya dipakai dalam proses asimilasi, yang sisanya dapat digunakan dalam pembentukan organ tanaman atau dapat dijadikan sebagai komponen hasil tanaman. Menurut Lakitan (2001) penambahan kandungan klorofil tanaman mampu mengoptimalkan proses asimilasi tanaman hingga asimilat yang terbentuk lebih banyak, maka akan berpengaruh pada pertambahan ukuran tanaman.

Tabel 6. Laju Pertumbuhan Nisbi (LPN) tanaman bawang merah Varietas Crok, Super Biru, Tiron, Lokal Wamena dan Bima

\begin{tabular}{lcccc}
\hline \multirow{2}{*}{ Varietas } & \multicolumn{3}{c}{ Perlakuan NASA } & \multirow{2}{*}{ Rerata } \\
\cline { 2 - 4 } & $0 \mathrm{ml}$ & $150 \mathrm{ml}$ & $250 \mathrm{ml}$ & \\
\hline Crok & $0,06 \mathrm{ab}$ & $0,05 \mathrm{ab}$ & $0,08 \mathrm{ab}$ & $0,08 \mathrm{a}$ \\
Tiron & $0,16 \mathrm{a}$ & $0,08 \mathrm{ab}$ & $0,06 \mathrm{ab}$ & $0,09 \mathrm{a}$ \\
Super Biru & $0,03 \mathrm{~b}$ & $0,070 \mathrm{ab}$ & $0,06 \mathrm{ab}$ & $0,05 \mathrm{a}$ \\
Lokal Wamena & $0,07 \mathrm{ab}$ & $0,08 \mathrm{ab}$ & $0,03 \mathrm{~b}$ & $0,06 \mathrm{a}$ \\
Bima & $0,07 \mathrm{ab}$ & $0,05 \mathrm{ab}$ & $0,04 \mathrm{~b}$ & $0,05 \mathrm{a}$ \\
Rerata & $0,07 \mathrm{a}$ & $0,075 \mathrm{a}$ & $0,05 \mathrm{a}$ & $(+)$ \\
\hline \multicolumn{4}{c}{ KK: 69,21} \\
\hline
\end{tabular}

Keterangan: Bilangan pada satu kolom dan/atau baris apabila diikuti dengan huruf yang sama membuktikan tidak adanya interaksi atau tidak berpengaruh nyata oleh DMRT dengan $\alpha=5 \% ;(+)$ : ada interaksi antara perlakuan yang dicoba

\section{Produksi}

Hasil penelitian terhadap produksi tanaman seperti bobot kering umbi yang dikering anginkan menunjukkan tidak berpengaruh nyata (Tabel 7). Pemberian perlakuan POC NASA tidak menunjukkan respon dalam produksi tanaman atau setiap perlakuan POC NASA berpengaruh sama dalam produksi tanaman. Secara mandiri terlihat jenis varietas menunjukkan adanya pengaruh nyata, yang ditunjukkan oleh varietas Super Biru $(1,38$ 
ton/ha), diduga dipengaruhi oleh faktor genetic tanaman tersebut (Gardner et al., 1991). Meskipun hasil penelitian terhadap kandungan klorofil menunjukkan pengaruh nyata, namun pada tingkat produksi menunjukkan tidak ada interaksi nyata dari perlakuan POC NASA yang diberikan terhadap varietas yang diuji coba. Akan tetapi, pada respon varietas menunjukkan varietas Super Biru menghasilkan bobot kering umbi tertinggi dan berpengaruh nyata terhadap varietas Tiron. Padahal varietas Tiron menghasilkan jumlah daun terbanyak yang diketahui berpengaruh pada jumlah asimilat yang terbentuk tinggi.

Tabel 7. Bobot kering umbi tanaman bawang merah (ton/ha) Varietas Crok, Super Biru, Tiron, Lokal Wamena dan Bima 13 MST

\begin{tabular}{lcccc}
\hline \multirow{2}{*}{ Varietas } & \multicolumn{3}{c}{ Perlakuan NASA } & \multirow{2}{*}{ Rerata } \\
\cline { 2 - 4 } Crok & $0,74 \mathrm{a} l$ & $150 \mathrm{ml}$ & $250 \mathrm{ml}$ & \\
Tiron & $0,72 \mathrm{a}$ & $0,51 \mathrm{a}$ & $0,98 \mathrm{a}$ & $0,95 \mathrm{ab}$ \\
Super Biru & $1,02 \mathrm{a}$ & $1,59 \mathrm{a}$ & $1,54 \mathrm{a}$ & $0,63 \mathrm{~b}$ \\
Lokal Wamena & $1,08 \mathrm{a}$ & $0,67 \mathrm{a}$ & $0,92 \mathrm{a}$ & $0,89 \mathrm{ab}$ \\
Bima & $1,07 \mathrm{a}$ & $1,24 \mathrm{a}$ & $1,21 \mathrm{a}$ & $1,17 \mathrm{ab}$ \\
Rerata & $0,92 \mathrm{a}$ & $1,02 \mathrm{a}$ & $1,06 \mathrm{a}$ & $(-)$ \\
\hline \multicolumn{4}{c}{ KK: 25,57} \\
\hline
\end{tabular}

Keterangan: Bilangan pada satu kolom dan/atau baris apabila diikuti dengan huruf yang sama membuktikan tidak adanya interaksi atau tidak berpengaruh nyata oleh DMRT dengan $\alpha=5 \% ;(+)$ : ada interaksi antara perlakuan yang dicoba.

Hal ini diduga kemampuan daya simpan asimilat hasil fotosintesis pada varietas Super Biru dapat bertahan dengan baik dibandingkan varietas Tiron yang diketahui dalam penelitian ini menunjukkan penghasil daun terbanyak dari varietas lainnya. Selain itu diduga adanya pengaruh suhu saat penjemuran benih bawang merah sebelum penanaman, yang menjadikan mengerasnya bagian terluar bawang yang membuat adanya perlindungan bagi kandungan air didalam umbi. Selain itu juga didukung oleh karakter genetik tanaman tanaman, keberadaan air dalam tubuh tanaman dan karakter morfologi tiap jenis tanaman yang berbeda (Jasmi et al., 2013).

\section{Kesimpulan}

Informasi penelitian membuktikan kalau tumbuh kembang tanaman bawang merah dipengaruhi oleh adanya interaksi perlakuan POC NASA dengan varietas tanaman bawang merah. Informasi yang diperoleh menandakan pengaruh nyata oleh kombinasi POC NASA $150 \mathrm{ml}$ dengan varietas Super Biru pada parameter tinggi tanaman dan bobot segar akar, kemudian perlakuan POC NASA $250 \mathrm{ml}$ dengan varietas Lokal Wamena pada parameter bobot kering daun, selanjutnya perlakuan POC NASA $250 \mathrm{ml}$ juga berpengaruh nyata dengan varietas Bima pada pengamatan kandungan klorofil a dan jumlah daun tanaman. 


\section{Ucapan Terimakasih}

Terima kasih kami ucapkan kepada Dirjen Riset dan Pengabdian kepada Masyarakat (DRPM) DIKTI RI atas dukungan finansial dalam pelaksanaan penelitian ini, dengan nomor kontrak: 01/L14/AK/KONTRAK-PENELITIAN-MULTIYEARS/2019.

\section{Daftar Pustaka}

Buhaira. (2007). Respon Kacang Tanah (Arachis hypogea L.) dan Jagung (Zea mays L.) Terhadap Beberapa Pengaturan Tanaman Jagung pada Sistem Tanam Tumpangsari. $J$ Agronomi, 11(1), 41-46.

Damari, C. (2012, Desember 24). Toko Online Pupuk Organik Nasa Natural Nusantara Cirebon. Retrieved from http://pupuknasaonline.blogspot.com/2011/11poc-nasa-html.

Elisabeth, D. W., Santosa, M. \& Herlina, N. (2013). Pengaruh pemberian berbagai komposisi bahan organik pada pertumbuhan dan hasil tanaman bawang merah (Allium ascalonicum L.). Jurnal Produksi Tanaman, 1(3), 21-29.

Gardner, F. P., Pearce, R. B., \& Mitchell, R. L. (1991). Fisiologi Tanaman Budidaya. Jakarta, Indonesia: UI Press

Jasmi, Sulistyaningsih, E. \& Indradewa, D. (2013). Pengaruh Vernalisasi Umbi Terhadap Pertumbuhan, Hasil dan Pembungaan Bawang Merah (Allium cepa L. Aggregatum group) di Dataran Rendah. Jurnal Ilmu Pertanian, 16(1), 42 - 57.

Juanda, H., Nugrahini T., \& Mahdalena. (2018). Pengaruh Pemberian Pupuk Organik Cair Nasa dan Pupuk Kompos Terhadap Pertumbuhan Tanaman Kenaf (Hibiscus cannabinus L). Agrifarm: Jurnal Ilmu Pertanian, 7(1), 6-9. https://doi.org/10.24903/ajip.v7i1.364

Lakitan, B. (2001). Dasar-dasar Fisiologi Tumbuhan. Jakarta, Indonesia: PT. Raja Grafindo Persada.

Nasaruddin \& Rosmawati. (2011). Pengaruh pupuk organik cair (POC) hasil fermentasi daun gamal, batang pisang, dan sabut kelapa terhadap pertumbuhan bibit kakao. Jurnal Agrisistem, 7(1), 29-37.

Natural Nusantara. (2004). Panduan Produk POC Nasa. Yogyakarta, Indonesia: Karya Anak Bangsa.

Nugrahini T. (2013). Respon Tanaman Bawang Merah (Allium ascolonicum L.) Varietas Tuk Tuk Terhadap Pengaturan Jarak Tanam Dan Konsentrasi Pupuk Organik Cair NASA. Jurnal Ziraa'ah, 36(1), 60-65. http://dx.doi.org/10.31602/zmip.v36i1.27

Nur, E. S. (2010). Pengaruh Pemupukan N dan K pada Pertumbuhan dan Hasil Tanaman Talas yang Ditanam di Lahan Kering. Akta Agrosia. 13 (1), 1 - 7.

Prihmantoro, H. (1999). Memupuk Tanaman Sayuran. Jakarta, Indonesia: Penebar Swadaya.

Putri, H. A. (2011). Pengaruh pemberian beberapa konsentrasi pupuk organik cair lengkap (POCL) bio sugih terhadap pertumbuhan dan hasil tanaman jagung manis (Zea mays $\begin{array}{llll}\text { Saccharata Sturt.) (Thesis). } & \text { Retrieved from }\end{array}$ http://repository.unand.ac.id/16777/1/Jurnal1.pdf

Samad, S. (2008). Respon Pupuk Kandang Sapi dan KCL terhadap Pertumbuhan dan Produksi Bawang Merah (Alium ascalanicum L.), Buletin Penelitian. Makasar, Indonesia: Lembaga Penelitian Universitas Hasanuddin.

Samad, S. (2012). Pengaruh Pupuk Organik Terhadap Pertumbuhan dan Produksi Tanaman Bawang Merah Di Lahan Kering Dataran Rendah (Thesis). Retrieved from https://unkhair.ac.id/banners/repository-unkhair/

Singh, S. K. \& Reddy, V. R. (2014). Combined effects of phosphorus nutrition and elevated carbon dioxide concentration on chlorophyll fluorescence, photosynthesis, and nutrient 
efficiency of cotton. J. Plant Nutr. Soil Sci., 177(6), 1 - 11. https://doi.org/10.1002/jpln.201400117

Supariadi, Yetti, H., \& Yoseva, S. (2017). Pengaruh Pemberian Pupuk Kandang dan Pupuk $\mathrm{N}$, P, dan $\mathrm{K}$ terhadap Pertumbuhan dan Produksi Tanaman Bawang Merah (Alium ascolanicum, L.). JOM FAPERTA, 4(1), 1 - 13.

Tuhuteru, S., Sulistyaningsih, E. \& Wibowo, A. (2019). Aplikasi Plant Growth Promoting Rhizobacteria dalam Meningkatkan Produktivitas Bawang Merah di Lahan Pasir Pantai. J. Agron. Indonesia, 47(1), 53-60. https://doi.org/10.24831/jai.v47i1.22271

Tuhuteru, S., Inrianti, Maulidiyah, Nurdin M. (2020). Effect of Organic Liquid Fertilizer to Increase Productivity on The Sub-Optimal Land of Wamena, Indonesia. AAB Bioflux $12(1), 22-33$.

Umarie, I., Widarti, W., Wijaya, I., \& Hasbi, H. (2018). Pengaruh Warna Naungan Plastik dan Dosis Pupuk Organik Kompos Terhadap Pertumbuhan Bawang Merah (Allium ascalonicum L.). Jurnal Agroqua, 16(2), 129-131. https://doi.org/10.32663/ja.v16i2.458

Von Caemmerer, S. \& Farquhar, G. D. (1981). Some relationship between the biochemistry of photosynthesis and the gas exchange of leaves. Planta, 153(4), 376-387.

Waluyo, N. \& Sinaga R. (2015). Bawang Merah. Bandung, Indonesia: Iptek Tanaman Sayuran. 